OPEN ACCESS

Edited by:

Yuji Morita,

Aichi Gakuin University, Japan

Reviewed by:

Kenneth C. Keiler,

Pennsylvania State University, USA

Reynald Gillet,

University of Rennes 1, France

Andrea M. Mitchell,

University of Birmingham, UK

*Correspondence:

Mónica Amblar

mamblar@isciii.es

Adela G. de la Campa

agcampa@isciii.es

tPresent address:

Joana Wilton

Gene Regulation/Microenvironments for New Therapies Lab, Instituto de Investigação e Inovação em Saúde,

Universidade do Porto, Porto,

Portugal

Specialty section:

This article was submitted to Antimicrobials, Resistance

and Chemotherapy,

a section of the journal

Frontiers in Microbiology

Received: 03 November 2016 Accepted: 23 December 2016

Published: 10 January 2017

Citation:

Brito L, Wilton J, Ferrándiz MJ, Gómez-Sanz A, de la Campa AG

and Amblar M (2017) Absence

of tmRNA Has a Protective Effect against Fluoroquinolones

in Streptococcus pneumoniae.

Front. Microbiol. 7:2164

doi: 10.3389/fmicb.2016.02164

\section{Absence of tmRNA Has a Protective Effect against Fluoroquinolones in Streptococcus pneumoniae}

\author{
Liliana Brito ${ }^{1}$, Joana Wilton ${ }^{11}$, María J. Ferrándiz², Alicia Gómez-Sanz', \\ Adela G. de la Campa ${ }^{2,3 *}$ and Mónica Amblar ${ }^{*}$ \\ ' Unidad de Patología Molecular del Neumococo, Centro Nacional de Microbiología, Instituto de Salud Carlos III, Madrid, \\ Spain, ${ }^{2}$ Unidad de Genética Bacteriana, Centro Nacional de Microbiología, Instituto de Salud Carlos III, Madrid, Spain, \\ ${ }_{3}^{3}$ Presidencia, Consejo Superior de Investigaciones Científicas, Madrid, Spain
}

The transfer messenger RNA (tmRNA), encoded by the ssrA gene, is a small noncoding RNA involved in trans-translation that contributes to the recycling of ribosomes stalled on aberrant mRNAs. In most bacteria, its inactivation has been related to a decreased ability to respond to and recover from a variety of stress conditions. In this report, we investigated the role of tmRNA in stress adaptation in the human pathogen Streptococcus pneumoniae. We constructed a tmRNA deletion mutant and analyzed its response to several lethal stresses. The $\triangle$ ssrA strain grew slower than the wild type, indicating that, although not essential, tmRNA is important for normal pneumococcal growth. Moreover, deletion of tmRNA increased susceptibility to UV irradiation, to exogenous hydrogen peroxide and to antibiotics that inhibit protein synthesis and transcription. However, the $\triangle S s r A$ strain was more resistant to fluoroquinolones, showing twofold higher MIC values and up to 1000-fold higher survival rates than the wild type. Deletion of SmpB, the other partner in trans-translation, also reduced survival to levofloxacin in a similar extent. Accumulation of intracellular reactive oxygen species associated to moxifloxacin and levofloxacin treatment was also highly reduced ( 100-fold). Nevertheless, the $\triangle S s r A$ strain showed higher intracellular accumulation of ethidium bromide and levofloxacin than the wild type, suggesting that tmRNA deficiency protects pneumococcal cells from fluoroquinolone-mediated killing. In fact, analysis of chromosome integrity revealed that deletion of tmRNA prevented the fragmentation of the chromosome associated to levofloxacin treatment. Moreover, such protective effect appears to relay mainly on inhibition of protein synthesis, since a similar effect was observed with antibiotics that inhibit that process. The emergence and spread of drugresistant pneumococci is a matter of concern and these results contribute to a better comprehension of the mechanisms underlying fluoroquinolones action.

Keywords: Streptococcus pneumoniae, tmRNA, trans-translation, stress adaptation, antibiotic resistance, fluoroquinolones, chromosomal fragmentation, reactive oxygen species

\section{INTRODUCTION}

The transfer messenger RNA (tmRNA) is a ubiquitous specialized small non-coding RNA encoded by the $s s r A$ gene that functions as both a tRNA and an mRNA. It works together with the SmpB protein in the trans-translation system, a quality control pathway that rescues ribosomes stalled on non-stop mRNAs (Keiler et al., 1996; Karzai et al., 1999, 2000). During trans-translation, the tmRNA-SmpB complex shifts the translation of the nascent 
peptide from the aberrant mRNA to the tmRNA-coding sequence, allowing resumption of translation while targeting the peptide for degradation and recycling ribosomes (Giudice et al., 2014; Shimizu, 2014). Accumulation of stalled ribosomes is toxic and they need to be rescued, otherwise, the cell would rapidly be depleted of translational ribosomes and protein synthesis would come to halt. Some bacteria have alternative backup systems that use either ArfA or ArfB factors to recognize no-stop complexes, promote hydrolysis of the peptidyl-tRNA and release the stalled ribosome (Chadani et al., 2010, 2011; Schaub et al., 2012; Keiler and Feaga, 2014). Impairment of trans-translation leads to a wide variety of phenotypes, likely influenced by the status of ArfA and/or ArfB. These phenotypes range from very subtle growth defects to lethality, but the most common are associated to defects in pathogenicity and stress-adaptation (Oh and Apirion, 1991; Komine et al., 1994; Julio et al., 2000; Muto et al., 2000; Okan et al., 2006; Li et al., 2008; Barends et al., 2010; Nichols et al., 2011; Mann et al., 2012; Svetlanov et al., 2012; Mu et al., 2013), or to increased sensitivity to antibiotics targeting translation (de la Cruz and Vioque, 2001; Abo et al., 2002; Vioque and de la Cruz, 2003; Luidalepp et al., 2005; Okan et al., 2006; Nichols et al., 2011; Svetlanov et al., 2012). In addition to quality control pathways, some genetic regulatory circuits use trans-translation to control gene expression, and diverse bacteria require trans-translation when they execute large changes in their genetic programs (Abo et al., 2000; Christensen and Gerdes, 2003; Christensen et al., 2003; Keiler and Shapiro, 2003; Ranquet and Gottesman, 2007; Keiler, 2008; Kobayashi et al., 2008). Therefore, the contribution of tmRNA and the trans-translation mechanism to cell survival differs among bacteria, and key questions regarding their utility remain unanswered.

We wanted to investigate the role of the tmRNA in the human pathogen Streptococcus pneumoniae. This bacterium is responsible for a wide spectrum of human diseases, ranging from mild otitis media to more severe infections such as meningitis, sepsis, or endocarditis (WHO, 2007) ${ }^{1}$. It is the most common bacterial cause of community-acquired pneumonia and the leading cause of vaccine-preventable deaths in children $<5$ years old (O'Brien et al., 2009). Treatment of pneumococcal diseases is hampered by the emergence and spread of drugresistant strains to traditionally effective agents, including betalactam antibiotics (Jacobs et al., 2003) and macrolides (Sahm et al., 2001). Fluoroquinolones (FQs), such as levofloxacin (LVX) and moxifloxacin (MOX), are currently used for the treatment of pneumococcal pneumonia in adult patients. These antibiotics inhibit type II DNA topoisomerases, ubiquitous enzymes that manage DNA topology and solve topological problems associated with DNA replication, transcription, and recombination (Champoux, 2001). It has been proposed that several FQs require ongoing protein synthesis to cause cell death, and that protein synthesis inhibitors may protect from chromosome fragmentation (Chen et al., 1996; Malik et al., 2006, 2007). In addition, reactive oxygen species (ROS) such as superoxide, hydrogen peroxide $\left(\mathrm{H}_{2} \mathrm{O}_{2}\right)$ and hydroxyl radical, contribute to FQ-mediated killing (Dwyer et al., 2007, 2014;

${ }^{1}$ http://www.who.int
Kohanski et al., 2007; Wang and Zhao, 2009; Wang et al., 2010). In S. pneumoniae, the mechanisms leading to ROS accumulation mediated by LVX and MOX have been recently elucidated (Ferrándiz and de la Campa, 2014; Ferrándiz et al., 2016). Both FQs induce global transcriptional responses that, although through different pathways, ultimately stimulate the Fenton reaction, increasing ROS accumulation and contributing to cell death.

Expression of tmRNA in the pneumococcus was recently demonstrated (Kumar et al., 2010; Acebo et al., 2012; Mann et al., 2012; Wilton et al., 2015) and, although no functional studies have been reported so far, its deficiency has strong effects in pathogenesis. In fact, ssrA inactivation reduced the ability to adhere and to invade endothelial cells, reduced the fitness and competitive index in lungs and causes attenuation in invasive diseases upon intranasal challenge (Mann et al., 2012). Regarding SmpB, its partner in trans-translation, it has been demonstrated that expression of the pneumococcal SmpB protein is induced under cold-shock and that its levels are regulated by RNase $\mathrm{R}$, an exoribonuclease involved in degradation of faulty mRNAs released from stalled ribosomes during transtranslation (Richards et al., 2006; Moreira et al., 2012). However, a direct link between trans-translation and survival to stress or antibiotic susceptibility/resistance, have never been established in S. pneumoniae.

The aim of the present study was to investigate the role of tmRNA in adaptation of $S$. pneumoniae to environmental conditions and antibiotic stress. We examined how the absence of tmRNA affects survival to several lethal environmental conditions and the activity of chemically unrelated antibiotics, some of which are commonly used in clinical practice. We showed that tmRNA deficiency had a detrimental effect on growth and was more sensitive to $\mathrm{UV}, \mathrm{H}_{2} \mathrm{O}_{2}$ and to a variety of antibiotics. However, deletion of tmRNA highly increased bacterial survival against FQs, decreased accumulation of intracellular ROS and reduced chromosomal fragmentation. This is the first study reporting a higher FQ-resistance phenotype associated to tmRNA deficiency, which has been generally considered as a stress-adaptation RNA.

\section{MATERIALS AND METHODS}

\section{Bacterial Strains, Plasmids, Growth Conditions, and Transformation}

Streptococcus pneumoniae strains and plasmids used in this study are described in Table 1. Pneumococci were grown as static cultures either in Todd-Hewitt medium supplemented with $0.5 \%$ of yeast extract (THY), or in a casein hydrolasebased medium (AGCH) supplemented with $0.3 \%$ sucrose and $0.2 \%$ of yeast extract $(\mathrm{A}+\mathrm{SY})$. All constructs and cloning experiments were carried out in the pneumococcal R6 strain. TIGR4 cells were transformed as previously described (Acebo et al., 2012) and plated onto blood agar plates. R6 cells were transformed as described previously (Lacks et al., 1986) and transformants were plated on $\mathrm{A}+\mathrm{SY}$ media plates containing $1 \%$ agar. Incubations were performed at $37^{\circ} \mathrm{C}$ in a $5 \% \mathrm{CO}_{2}$ 
TABLE 1 | Bacterial strains and plasmids used in this study.

\begin{tabular}{|c|c|c|}
\hline Bacterial strain & Description & Source \\
\hline TIGR4 & $\begin{array}{l}\text { Capsular type } 4 \text { clinical isolate } \\
\text { strain TIGR4 }\end{array}$ & Tettelin et al., 2001 \\
\hline $\mathrm{TIGR} 4 \Delta s s r A$ & TIGR4 ssrA::Kmr & This study \\
\hline $\mathrm{TIGR} 4 \Delta s m p B$ & TIGR4 smpB::Km & Moreira et al., 2012 \\
\hline R6 & $\begin{array}{l}\text { Non-encapsulated strain derived } \\
\text { from the capsular type } 2 \text { clinical } \\
\text { isolate strain D39 }\end{array}$ & Laboratory collection \\
\hline $\mathrm{R} 6 \Delta s s r A$ & $\mathrm{R} 6 \mathrm{ssr} A:: K m^{r}$ & This study \\
\hline $\mathrm{R} 6 \Delta s s r A(\mathrm{ROM})$ & $\mathrm{R} 6 \Delta s s r A[\mathrm{pROM}]$ & This study \\
\hline $\operatorname{R} 6 \Delta s s r A\left(s s r A^{+}\right)$ & $\mathrm{R} 6 \Delta s s r A[\mathrm{pROM}-\mathrm{TM}]$ & This study \\
\hline \multicolumn{3}{|l|}{ Plasmids } \\
\hline pLS1ROM & & Ruiz-Masó et al., 2012 \\
\hline pROM & pLS1ROM lacking PM promoter & This study \\
\hline pROM-TM & $\begin{array}{l}\text { pROM containing tmRNA } \\
\text { chromosomal fragment }\end{array}$ & This study \\
\hline
\end{tabular}

atmosphere. The pROM plasmid was constructed by deleting the $173 \mathrm{bp}$ fragment containing the maltose-inducible promoter (PM) of pLS1ROM (Ruiz-Masó et al., 2012). For this purpose, the whole plasmid (excluding $\mathrm{PM}$ ) was amplified through reverse PCR using pROM-F-Xba2 and pROM-R-Xba2 primers (Table 2). The fragment was then digested with XbaI and further ligated to obtain pROM. The pROM-TM plasmid was obtained by cloning a 531 bp chromosomal region containing the entire tmRNA encoding gene ssrA gene (including its own promoter) into $\mathrm{pROM}$. This fragment was amplified by PCR from TIGR4 chromosomal DNA using Expand High Fidelity (Roche). Primers used were tmRNACj-F and tmRNACj-R (Table 2), which contained the BamHI and HindIII restriction sites, respectively. The PCR product was cloned into pROM vector making use of the BamHI and HindIII restriction sites, thus obtaining the pROM-TM plasmid, which was then transformed into R6 competent cells. Transformants were selected using $1 \mu \mathrm{g} / \mathrm{ml}$ of erythromycin and cloning was verified by DNA sequencing. Expression of tmRNA in trans was confirmed by Northern-blot as previously described (Acebo et al., 2012).

\section{Construction of Genetically Modified Strains}

The TIGR4 tmRNA deletion mutant (TIGR4 $\Delta s s r A$ ) was constructed by insertion-deletion of a kanamycin resistance cassette $\left(\mathrm{Km}^{\mathrm{r}}\right)$ through allelic replacement mutagenesis (Song et al., 2005). For this purpose, three fragments were generated by PCR. Two of them contained the upstream and downstream tmRNA regions and were obtained using oligonucleotide pairs tmRNA-F/tmRNAKmUp-R and tmRNAKmDown-F/tmRNA-R, respectively (Table 2 ). The third fragment, containing $\mathrm{Km}^{\mathrm{r}}$, was amplified from pR410 plasmid (Sung et al., 2001) using $\mathrm{KmN}-\mathrm{F}$ and $\mathrm{KmN}-\mathrm{R}$ primers (Table 2). Primers tmRNAKmUp$\mathrm{R}$ and tmRNAKmDown-F partially overlapped with $\mathrm{KmN}-\mathrm{F}$ and KmN-R, respectively, to allow further hybridization of up- and downstream fragments with the amplified $\mathrm{Km}^{\mathrm{r}}$ fragment. The three resulting PCR products were purified, mixed together, amplified using tmRNA-F and tmRNA-R primers, and used to transform strain TIGR4 (Figure 1A). Construction of the R6 tmRNA deletion strain (R6 $\Delta s r A)$ was performed through amplification of a $3744 \mathrm{bp}$ fragment encompassing tmRNA insertion/deletion from TIGR $4 \Delta s s r A$ chromosomal DNA using tmRNA-1 and tmRNA-2 primers (Table 2) and further transformation of R6. In both cases, transformants were selected with $250 \mu \mathrm{g} / \mathrm{ml}$ of $\mathrm{Km}$, and confirmed by PCR amplification with external oligonucleotides tmRNA-1 and tmRNA-2 and DNA sequencing.

\section{Hydrogen Peroxidase and Paraquat Sensitivity Assays}

Hydrogen peroxidase sensitivity assays were performed essentially as described by Pericone et al. (2003). Briefly, bacteria were grown in THY broth until an absorbance at $600 \mathrm{~nm}\left(A_{600}\right)$ of 0.2 and diluted twofold in the same medium containing $40 \mathrm{mM} \mathrm{H} \mathrm{O}_{2}$ (Sigma-Aldrich), resulting in an true exposure of $20 \mathrm{mM} \mathrm{H}_{2} \mathrm{O}_{2}$. Bacteria were incubated at $37^{\circ} \mathrm{C}$ for $30 \mathrm{~min}$ and reactions were stopped by adding $200 \mathrm{U}$ of bovine liver catalase (Sigma-Aldrich). Serial dilutions were plated in blood agar plates and incubated overnight at $37^{\circ} \mathrm{C}$ in a $5 \% \mathrm{CO}_{2}$

TABLE 2 | List of primers used in this study.

\begin{tabular}{|c|c|c|}
\hline Primer & Nucleotide sequence $5^{\prime}-3^{\prime}$ & Description \\
\hline $\operatorname{tmRNA}-\mathrm{F}$ & TTCTGTGTCAGGGTAAGTTCC & Up PCR fragment for $\Delta s s r A$ construction \\
\hline tmRNAKmUp-R & TTATCCATTAAAAATCAAACGGATCACATACCTAAGATGAAGCTATCT & \\
\hline tmRNA-R & ACTGAATCACCTCCTGTTATCG & Down PCR fragment for $\Delta s s r A$ construction \\
\hline tmRNAKmDown-F & TACGAGGAATITGTATCGATGTGGACGTGGGTTCGACT & \\
\hline $\mathrm{KmN}-\mathrm{F}$ & CCGTITGATIITAATGGATAA & $\mathrm{Km}^{\mathrm{r}}$ cassette for $\Delta s s r A$ construction \\
\hline $\mathrm{KmN}-\mathrm{R}$ & CATCGATACAAATTCCTCGTA & \\
\hline pLSROM-F-Xba2 & CGTCTGCAAAATACTCTAGAGATGGATCAAG & For pROM construction \\
\hline pLSROM-R-Xba2 & CTCACGAGACAGTCTAGAAAGTACAAAACCTCC & \\
\hline tmRNACj-F & CGCGGATCCTTCATCTTAGGTATGTGATITC & For ssrA cloning \\
\hline tmRNACj-R & GCGCAAGCTTGGTCTGTITGTGACTCCC & \\
\hline $\operatorname{tmRNA}-1$ & AATTATCCTGCGCTCCAGAA & For $\Delta s s r A$ construction and DNA sequencing \\
\hline tmRNA-2 & TाTCAAGACACGGCTGACA & \\
\hline
\end{tabular}

Underlined sequence indicates enzyme restriction sites. 
A
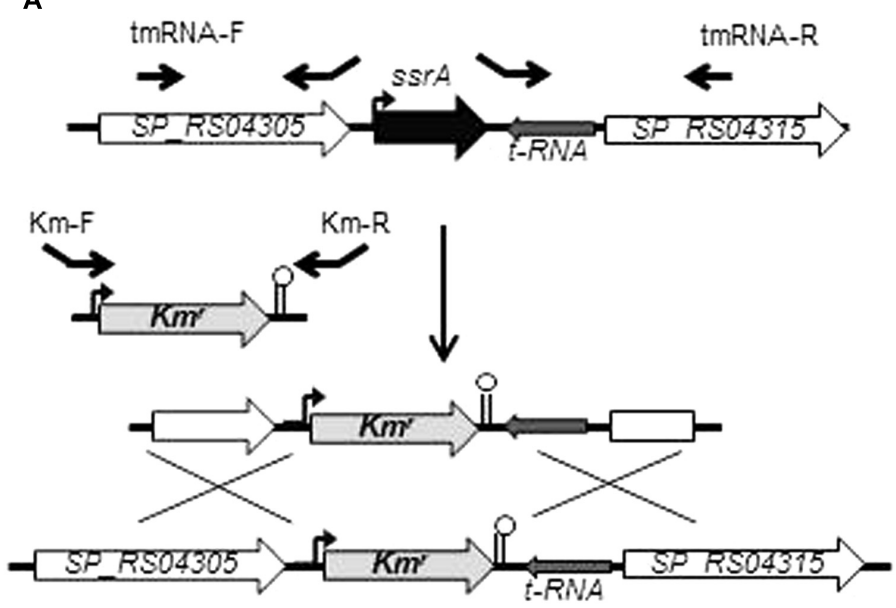

B

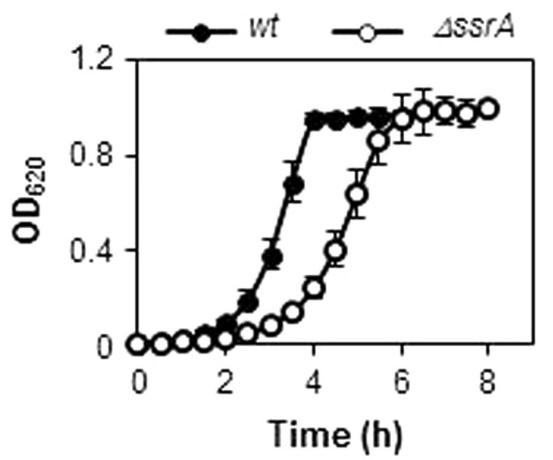

C

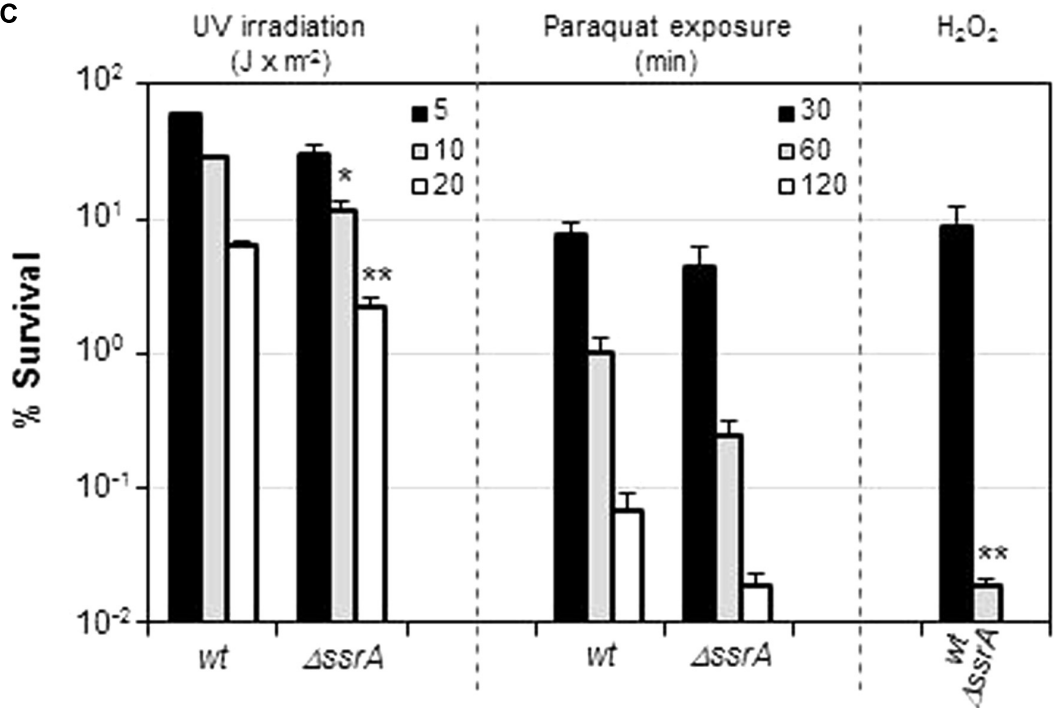

FIGURE 1 | Transfer messenger RNA (tmRNA) deficiency is detrimental under certain stress conditions. (A) Inactivation of $S S r A$ gene (black) by insertion/deletion of $\mathrm{Km}^{r}$ (light gray). Flanking ORFs (white) and tRNA gene (dark gray) are depicted. Promoters (curved arrows), terminators (stem-loop structures) and primers used (black arrows) are shown (B) Growth curves of wild type TIGR4 (wt) strain and its tmRNA deletion mutant $(\Delta s s r A)$ in THY broth at $37^{\circ} \mathrm{C}$.

(C) Survival of $w t$ and $\triangle S s r A$ upon treatment with $30 \mathrm{mM}$ paraquat at the indicated times, after UV irradiation at the intensities indicated, or after 30 min of exposure to $20 \mathrm{mM}$ of hydrogen peroxide. Survival was determined as described in Section "Materials and Methods." Values (mean $\pm \mathrm{SD}$ ) are the average of at least three independent experiments and the means were statistically compared using Student's $t$-test $\left({ }^{*} P<0.05 ;{ }^{* *} P<0.01\right)$.

atmosphere. Percentage of survival cells was calculated relative to the untreated control bacteria. Paraquat sensitivity assays were performed as previously described (Andisi et al., 2012). Bacteria were grown until $A_{600}=0.2$, and diluted twofold in the same medium with $30 \mathrm{mM}$ paraquat (Sigma-Aldrich) or without paraquat, and incubated at $37^{\circ} \mathrm{C}$ for 2 -h. Samples were taken at time intervals and the number of viable cells was determined by plating onto blood agar plates.

\section{Susceptibility to UV Irradiation Assays}

Susceptibility to UV irradiation assays were performed as previously described (Halpern et al., 2004). Cells were grown in A+SY medium to exponential phase (an $A_{620}$ of approximately 0.2 ). Serial dilutions were then plated and exposed to UV light at $254 \mathrm{~nm}$ at the indicated intensities. Percentage of survival was estimated by colony counting relative to untreated control samples. 


\section{Antibiotic Susceptibility Studies and Detection of Reactive Oxygen Species}

MICs were determined by the broth macrodilution method (Clinical and Laboratory Standards Institute, 2008). To measure lethal action of antibiotics, pneumococci were grown in $\mathrm{A}+\mathrm{SY}$ medium to $A_{620}=0.4$, diluted 100 -fold and treated with the antibiotic. Samples were withdrawn at time intervals and colony formation was determined by plating on drug-free blood agar plates. The percentage of surviving cells was calculated relative to untreated control samples. When indicated, $10 \mu \mathrm{g} / \mathrm{ml}$ of chloramphenicol or $0.3 \mu \mathrm{g} / \mathrm{ml}$ of erythromycin was added to the culture 10 min prior to FQ addition and maintained throughout treatment. Intracellular oxidation level upon FQ treatment was measured by ROS detection using dihydrorhodamine 123 dye (Sigma-Aldrich) as previously described (Ferrándiz and de la Campa, 2014). Results were expressed as relative fluorescence units (RFU) and were made relative to time point zero, and normalized according to the number of live cells at each time point.

\section{Ethidium Bromide Uptake and Efflux Studies}

Uptake of ethidium bromide (EtBr) was measured by fluorescence spectrophotometry as previously described (PérezBoto et al., 2015) with several modifications. Bacteria were grown at $37^{\circ} \mathrm{C}$ to mid-logarithmic phase $\left(A_{620}=0.4\right)$ in $\mathrm{A}+\mathrm{SY}$ medium. Cells were harvested, washed and suspended in phosphate saline buffer (PBS) ( $\mathrm{pH} 7.2$ ) with $0.2 \%$ glucose to $A_{620}=0.2$. After $10 \mathrm{~min}$ of incubation at $37^{\circ} \mathrm{C}$, bacteria were exposed to $2 \mu \mathrm{g} / \mathrm{ml}$ of $\mathrm{EtBr}$, with or without $20 \mu \mathrm{g} / \mathrm{ml}$ reserpine. Increase of fluorescence as $\mathrm{EtBr}$ entered the cells was directly recorded along $20 \mathrm{~min}$, measuring every $0.25 \mathrm{~s}$ at $530 \mathrm{~nm}$ (excitation wavelength) and $600 \mathrm{~nm}$ (emission wavelength) in a Varian Cary Eclipse Spectrophotometer (Agilent Technologies Spain S. L. Madrid, Spain). The mean of at least three independent experiments was obtained.

Measurement of EtBr efflux was based on previously described method (Jumbe et al., 2006). Bacterial suspensions at $A_{620}=0.2$ were prepared in PBS with $0.2 \%$ glucose as described above. Bacteria were then exposed to $\mathrm{EtBr}$ for $20 \mathrm{~min}$ at $37^{\circ} \mathrm{C}$ in the presence of reserpine to maximize $\mathrm{EtBr}$ loading into bacteria. Cells were collected by centrifugation and suspended in fresh $\mathrm{PBS}+0.2 \%$ glucose. Efflux of $\mathrm{EtBr}$ from cells was measured as fluorescence signal decrease during $20 \mathrm{~min}$.

\section{FQ Accumulation Measurements}

Accumulation of LVX on each strain was measured by fluorescence essentially as previously described (Piddock and Johnson, 2002). A starter culture was diluted 40 -fold in $100 \mathrm{ml}$ of $\mathrm{A}+\mathrm{SY}$ medium, and grown at $37^{\circ} \mathrm{C}$ to $A_{620}=0.5$. Cells were washed and concentrated 20 -fold in $0.1 \mathrm{M}$ sodium phosphate $\mathrm{pH} 7.0$, and the suspension was equilibrated for $10 \mathrm{~min}$ at $37^{\circ} \mathrm{C}$ prior to accumulation measurements. LVX was added at different concentrations and suspensions were incubated at $37^{\circ} \mathrm{C}$ for the indicated times. $0.5 \mathrm{ml}$ aliquots were withdrawn and added to $2.5 \mathrm{ml}$ of ice-cold $0.1 \mathrm{M}$ sodium phosphate, washed with the same buffer and resuspended in $0.1 \mathrm{M}$ glycine $\mathrm{pH}$ 3 to achieve cell lysis. After incubating at room temperature overnight, samples were centrifuged twice at $10000 \times g$ for $10 \mathrm{~min}$. LVX concentration in the supernatant was measured by fluorescence spectroscopy at $295 \mathrm{~nm}$ (excitation wavelength) and $496 \mathrm{~nm}$ (emission wavelength), and compared to a standard fluorescence curve previously obtained. Accumulation data were converted into $\mu \mathrm{g}$ of LVX per ml.

\section{Analysis of Chromosome Fragmentation by PFGE}

Chromosomal fragmentation was detected by pulsed-field gel electrophoresis (PFGE) as previously described (Ferrándiz et al., 2016). A starter culture was diluted 40 -fold in A+SY medium and grown at $37^{\circ} \mathrm{C}$ to $A_{620}=0.3$. Bacteria were then treated with $10 \times$ MIC of LVX and incubated at $37^{\circ} \mathrm{C}$ for an additional $30 \mathrm{~min}$. Cells were harvested, washed twice with wash buffer $(1 \mathrm{M} \mathrm{NaCl}, 10 \mathrm{mM}$ Tris $\mathrm{pH}$ 8) and inserted in solid agarose blocks for further lysis as described previously (Ferrándiz et al., 2016). Electrophoresis was performed in a Cheff-DR III system (Bio-Rad), for $20 \mathrm{~h}$ at $5.8 \mathrm{~V} / \mathrm{cm}$ with a 0.1 - to 40 -s switch-time ramp at $14^{\circ} \mathrm{C}$. Gels were stained with $0.5 \mu \mathrm{g} / \mathrm{ml} \mathrm{EtBr}$ for $1 \mathrm{~h}$ and further distained in water during the same time. Percentages of chromosomal fragmentation were estimated by quantification of relative band intensities in each lane, corresponding to fragmented (compression zone) and non-fragmented (retained in the well) DNA.

\section{RESULTS}

\section{Deficiency of tmRNA Reduces Bacterial Growth and Increases Sensitivity to Stress}

Transfer messenger RNA is a major actor in the transtranslation mechanism and, although its contribution to cell survival differs among bacteria, its inactivation is expected to diminish recovery from stress. To investigate the role of tmRNA in S. pneumoniae we constructed a TIGR4 tmRNA mutant (TIGR4 $\triangle s s r A$ ) by deletion of its $s s r A$ encoding gene and insertion of $\mathrm{Km}^{\mathrm{r}}$ (Figure 1A). Deletion of $s s r A$ increased the doubling time at $37^{\circ} \mathrm{C}$ from $42.8 \pm 1.9$ min (mean $\pm \mathrm{SD}$ ) to $\sim 61.7 \pm 2.4 \mathrm{~min}$ (Table 3). These results indicated that, although tmRNA is not essential for the pneumococcus, its absence has a detrimental effect on growth (Figure 1B). We next evaluated the sensitivity to various environmental stress conditions. TIGR4 $\Delta s s r A$ was 3 - to 4 -fold more susceptible than TIGR4 to $30 \mathrm{mM}$ paraquat, which induces formation of superoxide inside the cell (Figure 1C). However, these differences, although evident, were not statistically significant $(P=0.055$ after $60 \mathrm{~min}$ and $P=0.092$ after $120 \mathrm{~min}$ ). By contrast, TIGR4 $\Delta s s r A$ was significantly more susceptible to treatment with UV light at $254 \mathrm{~nm}$, with survival rates 2.5 -fold (at $10 \mathrm{~J} \times \mathrm{m}^{-2}$; $P=0.015)$ and threefold (at $\left.20 \mathrm{~J} \times \mathrm{m}^{-2} ; P=0.0027\right)$ lower than TIGR4 (Figure 1C). Moreover, addition of exogenous $\mathrm{H}_{2} \mathrm{O}_{2}$ was highly deleterious for TIGR $4 \Delta s r A$, whose survival was 
TABLE 3 | Doubling time of pneumococcal strains used.

\begin{tabular}{lcc}
\hline Strain & \multicolumn{2}{c}{ Duplication time (min) $^{\mathbf{1}}$} \\
\cline { 2 - 3 } & $\mathbf{3 7}^{\circ} \mathbf{C}$ & $\mathbf{3 0}^{\circ} \mathbf{C}$ \\
\hline TIGR4 & $42.8 \pm 1.9$ & n.d. \\
TIGR4 $\Delta s s r A$ & $61.7 \pm 2.4$ & n.d. \\
R6 & $48.6 \pm 0.9$ & $65.4 \pm 1.0$ \\
R6 $\Delta s s r A$ & $62.2 \pm 2.2$ & $95.7 \pm 4.5$ \\
R6 $\Delta s s r A(R O M)$ & $85.4 \pm 5.6$ & $108.1 \pm 10.1$ \\
R6 $\Delta s s r A\left(s s r A^{+}\right)$ & $41.0 \pm 2.4$ & $68.6 \pm 1.5$ \\
\hline
\end{tabular}

${ }^{1}$ Values were calculated from growth curves performed in A+SY medium at 37 or $30^{\circ} \mathrm{C}$ in a TECAN infinite F200 plate reader and are the average \pm standard deviation of, at least, three independent experiments. n.d., not determined.

TABLE 4 | In vitro antibiotic susceptibilities determined by macrodilution in TIGR4 and R6 strains of Streptococcus pneumoniae.

\begin{tabular}{|c|c|c|c|c|c|}
\hline \multirow[t]{2}{*}{ Drug } & \multicolumn{4}{|c|}{$M I C \mu g / m L^{1}$} & \multirow{2}{*}{$\begin{array}{c}\text { Fold } \\
\text { change }\end{array}$} \\
\hline & TIGR4 & TIGR4 $\Delta s s r A$ & R6 & $\mathrm{R} 6 \Delta s s r A$ & \\
\hline Chloramphenicol & 1 & 0.5 & n.d. & n.d. & $2 \downarrow$ \\
\hline Tetracycline & 0.125 & 0.062 & n.d. & n.d. & $2 \downarrow$ \\
\hline Erythromycin & 0.03 & 0.0075 & n.d. & n.d. & $4 \downarrow$ \\
\hline Rifampicin & 0.06 & 0.03 & n.d. & n.d. & $2 \downarrow$ \\
\hline Penicillin & 0.016 & 0.016 & n.d. & n.d. & \\
\hline Cefotaxime & 0.015 & 0.015 & n.d. & n.d. & \\
\hline Moxifloxacin & 0.25 & 0.50 & 0.125 & 0.25 & $2 \uparrow$ \\
\hline Levofloxacin & 0.50 & 1 & 0.25 & 0.50 & $2 \uparrow$ \\
\hline Ciprofloxacin & n.d. & n.d. & 0.50 & 1 & $2 \uparrow$ \\
\hline Norfloxacin & n.d. & n.d. & 4 & 8 & $2 \uparrow$ \\
\hline
\end{tabular}

${ }^{1}$ Results are the average of at least three independent replicates. n.d., not determined. ${ }^{2}$ Fold change denotes the ration between the values for the wild type strains and their corresponding $\Delta s s r A$ derivative.

reduced $\sim 400$-fold after 30 min of incubation with $20 \mathrm{mM} \mathrm{H}_{2} \mathrm{O}_{2}$ $(P=0.005)$ (Figure 1C). These results revealed the importance of tmRNA and the trans-translation mechanism in adaptation of S. pneumoniae to certain environmental stress conditions.

We then examined the effect of the ssrA deletion under antimicrobial stress and determined the MIC values of several drugs from different families (Table 4). Deletion of $s s r A$ lowered the MICs of antibiotics targeting translation, such as chloramphenicol (CM), erythromycin (EM) and tetracycline, and transcription, such as rifampicin, 2- or 4-fold, but had no effect with beta-lactams such as penicillin or cefotaxime, which interfere with cell wall synthesis. However, the MICs of MOX and LVX were higher for the $\triangle s s r A$ strain than for the wild type by 1 dilution factor (Table 4). Such difference, although low, suggested that the tmRNA deletion reduces susceptibility to these drugs.

\section{Absence of tmRNA Increases Resistance to FQs and Reduces ROS Production}

To confirm the apparent lower susceptibility of $\Delta s s r A$ and better understand the effect of tmRNA on FQ activity, we determined the survival of wild type and mutant strains upon treatment with different concentrations of LVX and MOX from 1 to $4 \mathrm{~h}$. The TIGR $4 \Delta s s r A$ was much more resistant to killing by both FQs at all times and concentrations tested, showing up to $\sim 150$ - (for LVX) and $\sim 100$-fold (for MOX) higher survival rates than the wild type (Figure $\mathbf{2 A}$ ). This effect was specific to FQs as no differences in survival were observed with the other bactericidal agent penicillin (Figure 2A). Moreover, this phenotype was associated to defects in trans-translation since similar survival rates to $5 \times$ MIC of LVX were observed with the $\triangle s m p B$ mutant lacking $S m p B$, the other indispensable partner for trans-translation (Figure 2A). Provided that FQ lethality is associated to ROS production we determined the internal levels of ROS in TIGR4 and TIGR $4 \Delta s s r A$ upon LVX and MOX treatment at the same time points and antibiotic concentrations. ROS accumulation in TIGR $4 \Delta s s r A$ was highly reduced compared to TIGR4, showing a decrease of more than $\sim 120$-fold after $2 \mathrm{~h}$ treatment with both antibiotics (Figure $2 \mathrm{~B}$ ). These results demonstrated that the higher survival rate exhibited by TIGR $4 \Delta s s r A$ is related with a reduction in ROS production.

To ensure that the less FQ-sensitive phenotype of the tmRNA deficiency was not related with the genetic background, a similar analysis was performed using strain R6. We constructed the R6 $\Delta s s r A$ strain and analyzed growth under different concentrations of LVX. As shown in Figure 3A, growth inhibition upon antibiotic treatment was lower in R6 $\Delta s r A$ than in R6, and the differences between strains increased proportionally with LVX concentration up to $1 \mu \mathrm{g} / \mathrm{ml}$. The study was extended to other FQs and the MIC values of LVX, MOX, ciprofloxacin (CPX), and norfloxacin (NFX) were determined. In all cases, the MICs were higher for R6 $\Delta s s r A$ than for R6 (Table 4), confirming less susceptibility to all FQs. We then compared survival of R6 and R6 $\Delta s r A$ strains upon treatment with the four distinct FQs (Figure 3B). As in the TIGR4 genetic background, the lethal action of the four FQs was reduced several 100-fold in the R6 $\Delta s s r A$, and this effect was associated with $>2$-log decrease in ROS accumulation after LVX treatment (Figure 3C). To attribute protection from FQ lethal activity to tmRNA deficiency, complementation experiments were performed. The pROM-TM plasmid containing the entire ssrA gene was constructed and introduced into R6 $\Delta s s r A$. Expression of tmRNA in trans in this strain was confirmed by Northern blot-analysis (Figure 3D). Survival during LVX treatment revealed that the complemented strain was killed to the same extent as R6, while R6 $\Delta s s r A$ with the empty vector did not (Figure 3B). Furthermore, since the potency of bactericidal compounds may increase with faster bacterial growth rate (Deitz et al., 1966), the possibility exists that the higher survival to FQs shown by R6 $\Delta s r A$ resulted from its slower growth. To exclude this possibility, we analyzed survival of R6 to $\mathrm{LVX}$ at $30^{\circ} \mathrm{C}$, which reduced the doubling time of wild type cells $(65.4 \pm 1.0 \mathrm{~min})$ to the same levels as the $\mathrm{R} 6 \Delta s s r A$ mutant at $37^{\circ} \mathrm{C}(62.2 \pm 2.2 \mathrm{~min})$ (Table 3$)$. Results showed that resistance to LVX of R6 indeed partially increased at $30^{\circ} \mathrm{C}$, showing 7.7- and 8.4-fold higher percentages of survival than at $37^{\circ} \mathrm{C}$ after 3 and $4 \mathrm{~h}$ treatment, respectively (Figure 3B). However, these values were far from those obtained with $\mathrm{R} 6 \Delta s s r A$ at $37^{\circ} \mathrm{C}$, which showed survival percentages of 
A
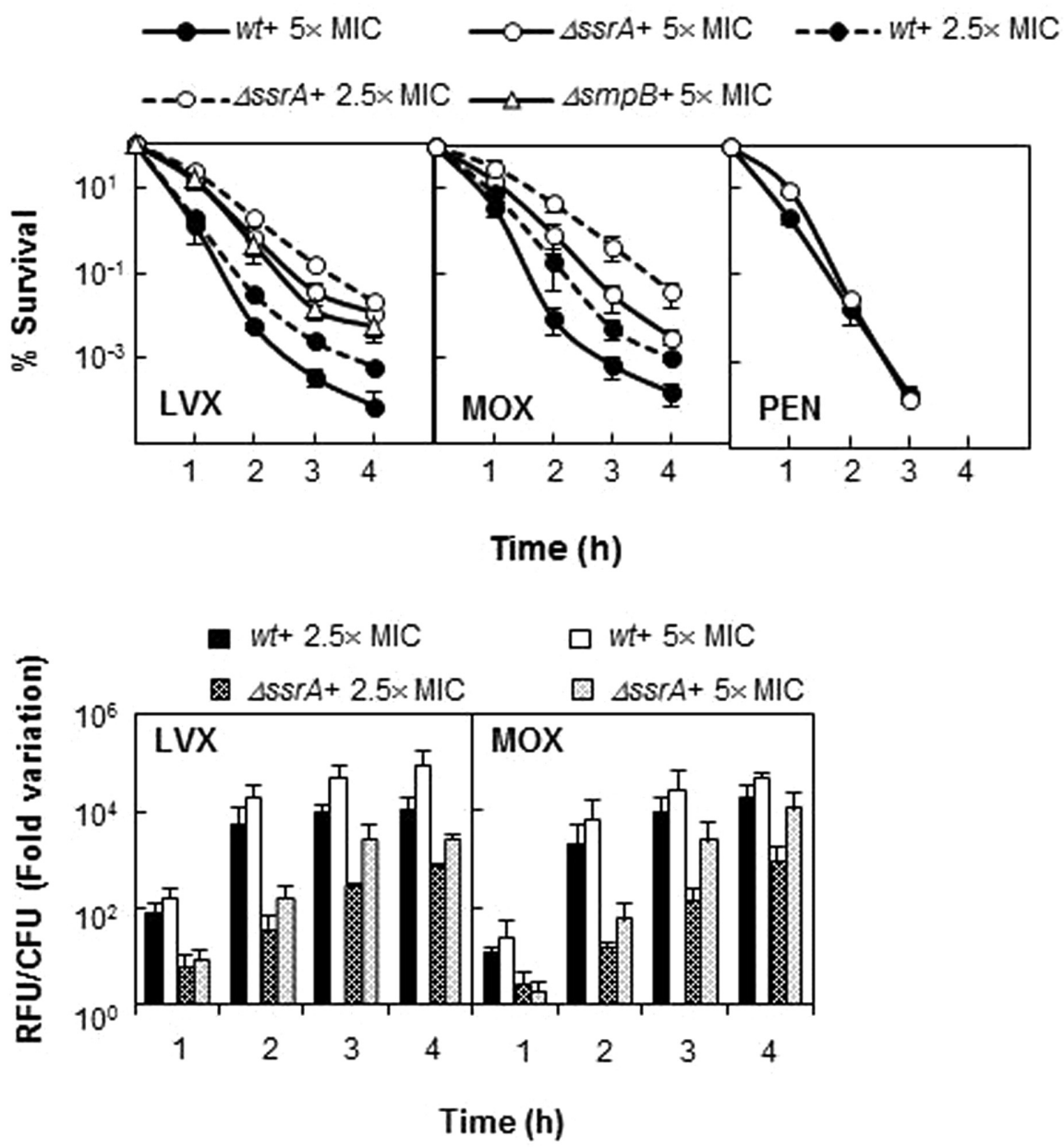

FIGURE 2 | Deletion of tmRNA reduces lethality of FQs but not of penicillin. (A) Percentage of survival of wt, $\Delta s s r A$ and TIGR4 $\Delta s m p B$ ( $\Delta s m p B$ ) strains upon treatment with LVX, MOX and/or penicillin (PEN). Exponentially growing cells were treated with each antibiotic at the concentration and times indicated. Survival was determined as described in Section "Materials and Methods." (B) Accumulation of ROS in wt and $\triangle$ ssrA strains upon treatment with 2.5 and $5 \times$ MIC of LVX and MOX were measured in the same samples as described in Section "Materials and Methods." RFU, relative fluorescence units; fluorescence units were divided by the number of viable cells and normalized to time zero and no antibiotic treatment condition. Values (mean \pm SD) of at least three independent experiments are shown. The MIC values used were those determined in Table 4.

about 1100- and 450-fold higher after 3 and 4 h of LVX-treatment, respectively.

From these experiments we can conclude that $\Delta s s r A$ strain is better able to survive to the lethal effect of FQs than $s s r A^{+}$cells and that this phenotype does not relay only in growth defect, but in another mechanism of protection directly linked with defects in trans-translation.

\section{tmRNA Deficiency Increases FQ Accumulation}

The less sensitive phenotype of the tmRNA deletion mutant could be due to a lesser accumulation of FQs inside the cell, due to changes in membrane permeability. To explore this possibility, we conducted experiments comparing EtBr uptake and efflux in both R6 and R6 $\Delta s s r A$ strains. Results revealed that EtBr uptake was higher in R6 $\Delta s s r A$ than in R6 and, simultaneously, the efflux was lower (Figure 4A). As a consequence, internal levels of EtBr in R6 $6 s s r A$ were higher than in R6. Addition of reserpine, an efflux pump inhibitor in streptococci (Ferrándiz et al., 1999; Piddock and Johnson, 2002), considerably increased EtBr accumulation in the wild type strain, while the effect in R6 $\Delta s s r A$ was much lower. Remarkably, EtBr levels accumulated in R6 upon reserpine addition were equivalent to the levels in R6 $\Delta s r A$ without the inhibitor. These results indicate that the efflux pumps in R6 $\Delta s s r A$ are less active in exporting $\mathrm{EtBr}$, leading to higher accumulation of this drug. We analyzed whether the observed effect was specific to EtBr or whether the accumulation of LVX was also increased in the $\Delta s s r A$ mutant. We examined levels of intracellular LVX upon treatment with different antibiotic concentrations and different exposure times. Again, R6 $\Delta s s r A$ accumulated higher amounts of LVX than R6 in all cases (Figure 4B). These results suggest that the 
A

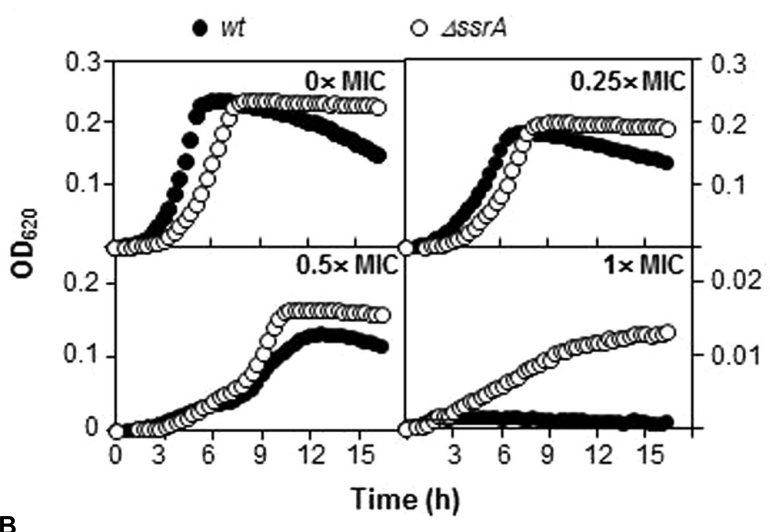

C

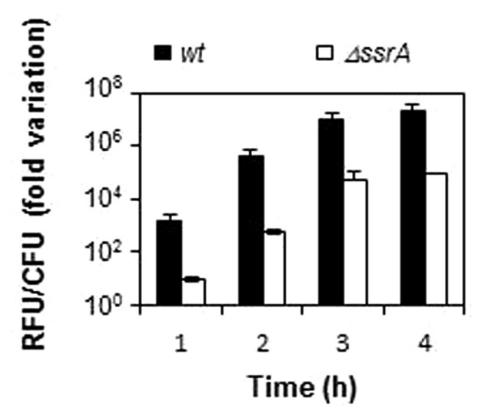

D
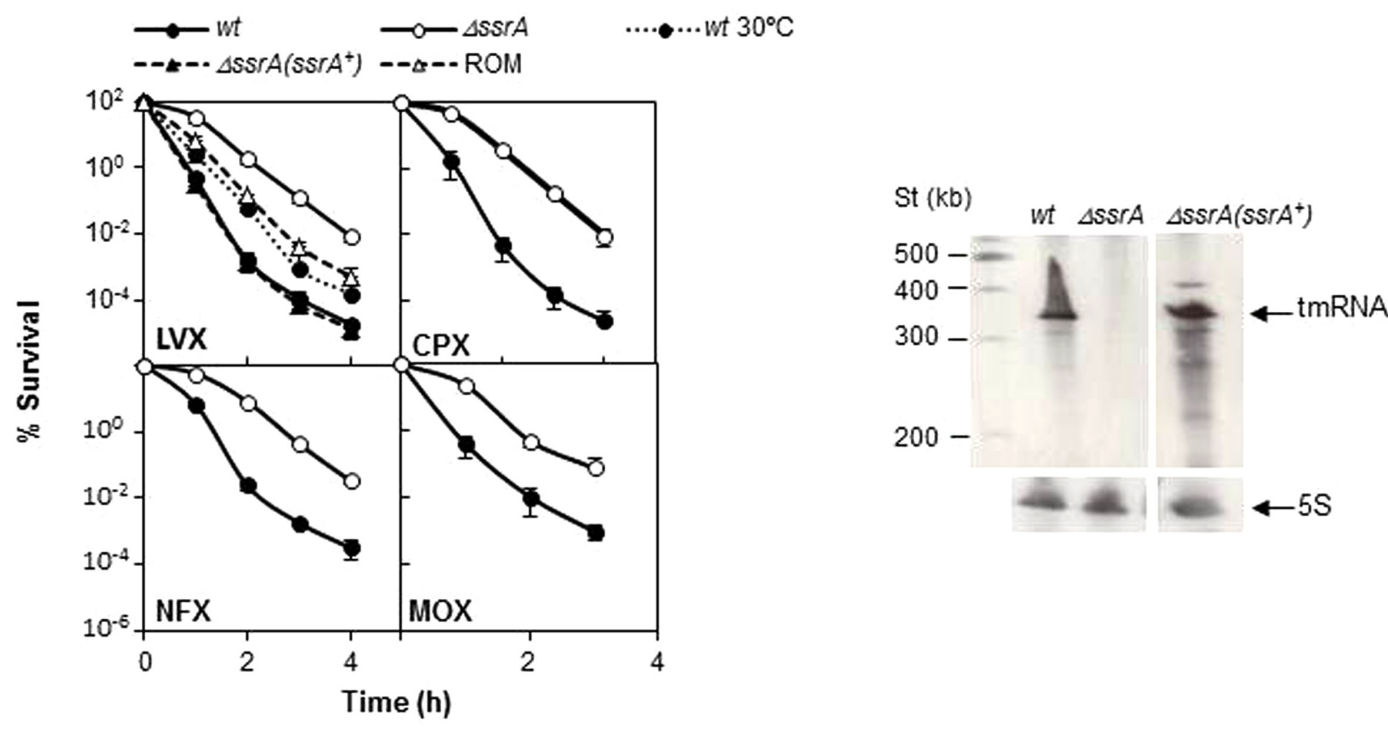

FIGURE 3 | Transfer messenger RNA deficiency protects from FQs lethal action. (A) Wild type R6 strain (wt) and its tmRNA deletion mutant ( $\triangle s s r A$ ) were grown under different LVX concentrations in $\mathrm{A}+\mathrm{Y}$ medium. Growth was followed by turbidity $\left(\mathrm{OD}_{620 \mathrm{~nm}}\right)$ in a TECAN infinite F200 plate reader at $37^{\circ} \mathrm{C}$.

(B) Percentage of survival to different $\mathrm{FQs}$ of $w t, \triangle s s r A$, the complemented strain containing the pROM-TM $\left(\Delta s s r A\left(s s r A^{+}\right)\right)$and the $\triangle s s r A$ containing the empty vector (ROM) at $37^{\circ} \mathrm{C}$, and of $w t$ at $30^{\circ} \mathrm{C}$. Exponentially growing cells were treated with $5 \times$ MIC (as determined in Table 4) of LVX, ciprofloxacin (CPX), norfloxacin (NFX), or MOX for the times indicated. After incubation, survival was determined as described in Section "Materials and Methods." (C) Accumulation of ROS in wt and $\triangle S S r A$ upon addition of $5 \times$ MIC of LVX was measured as described in Section "Materials and Methods." RFU; fluorescence units were divided by the number of viable cells and normalized to time zero and no antibiotic treatment condition. (D) Northern-blot showing tmRNA expression in wt, $\Delta s s r A$ and $\Delta s s r A\left(s s r A^{+}\right)$. Bands corresponding to tmRNA and the control 5S rRNA are indicated by arrows. Northern-blots were performed as described (Acebo et al., 2012). Values (mean \pm SD) of at least three independent experiments are shown. MIC values were determined in Table 4.

absence of tmRNA indeed induces changes in S. pneumoniae membrane permeability. However, instead of reducing levels of EtBr and LVX inside the cell, these changes lead to their higher accumulation.

\section{Absence of tmRNA Protects from Chromosomal Fragmentation Associated to FQs}

Since the lethal effect of FQs has been correlated with chromosome fragmentation, we examined LVX-associated DNA breakage in R6 and R6 $\operatorname{ssr} A$ after $30 \mathrm{~min}$ of exposure to $10 \times$
MIC of LVX (Figure 5). Percentage of the bands corresponding to the compression zone (CZ, containing the large size nicked fragments of chromosomal DNA) was used to estimate chromosomal fragmentation. As shown in Figures 5A,B, LVX treatment induced a $16.7 \pm 1.6 \%$ (mean \pm SD) fragmentation in R6, compared with the $6.5 \pm 1.9 \%$ observed without the antibiotic. However, such increase was not observed in R6 $\Delta s s r A$, whose fragmentation levels with and without LVX were similar (7.1 \pm 1.25 and $6.7 \pm 2.6 \%$, respectively). Interestingly, overexpression of tmRNA in the complemented strain completely restored the initial levels of fragmentation to $16.5 \pm 2.7 \%$, while the empty vector did not $(8.8 \pm 2.2 \%)$. 


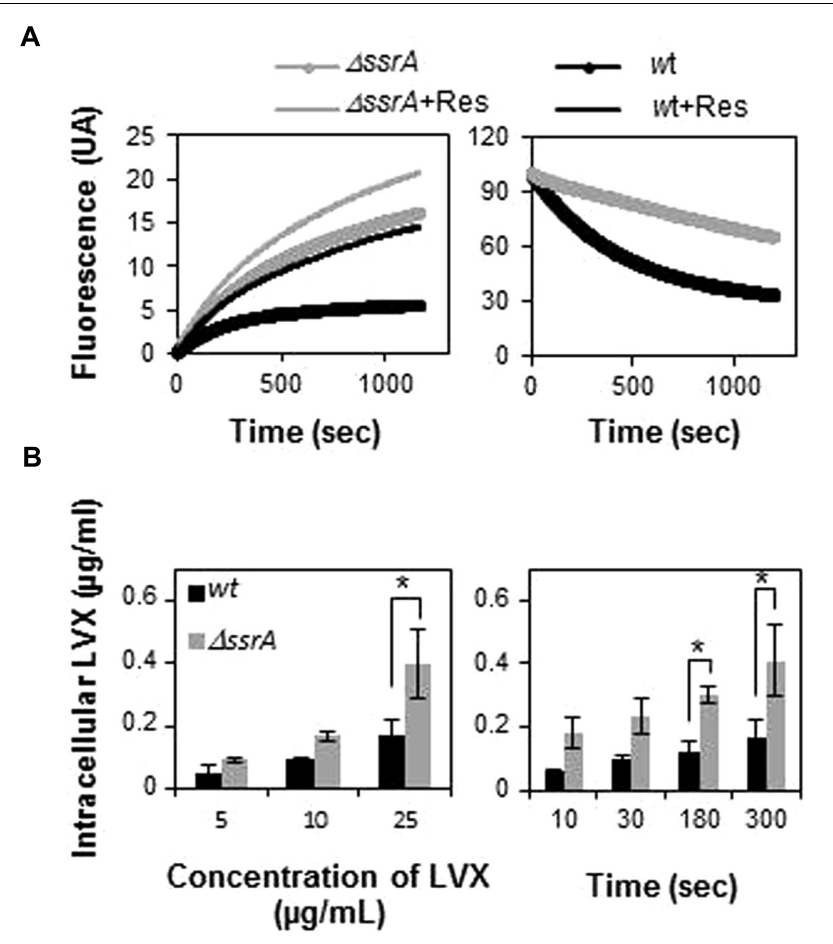

FIGURE 4 | Transfer messenger RNA deficiency leads to higher intracellular accumulation of drugs. (A) EtBr uptake (left panel) and efflux (right panel) of R6 (wt) and R6 $\Delta s s r A(\Delta s s r A)$ strains during 20 min was measured as described in Section "Materials and Methods." Fluorescence intensity represents levels of intracellular $\mathrm{EtBr}$. The change in fluorescence is normalized to the initial levels to allow for direct comparison. Fluorescence was directly recorded during 20 min after addition of $\mathrm{EtBr}$ in the presence (+Res) or in the absence of reserpine. (B) Fluorometric measurement of intracellular accumulation of levofloxacin (LVX) in wt and $\triangle$ ssrA at different LVX concentrations (left panel) and time points (right panel), as described in Section "Materials and Methods." Three to five independent experiments were conducted and the mean values were statistically compared using Student's t-test $\left({ }^{*} P<0.05\right)$

Therefore, we can conclude that the absence of tmRNA protects from chromosome fragmentation associated to FQs treatment.

Absence of tmRNA is expected to slow down translation due to lack of turnover of stalled ribosomes and it is known that in Escherichia coli several FQs require active protein synthesis to cause cell death (Malik et al., 2006, 2007). Therefore, it is possible that the protective effect of $\triangle s s r A$ could be related to a lower protein synthesis rate. To explore this possibility, we tested the effect of the protein inhibitor CM as a blocking agent of FQ-lethal action in the pneumococcus. For this purpose, bacterial cultures were treated with $10 \times$ MIC of CM for $10 \mathrm{~min}$, and then different concentrations of LVX were added for 1 additional hour. As shown in Figure 5C, incubation with CM drastically reduced cell death in R6, increasing survival from $\sim 0.1 \%$ in the absence of the protein inhibitor, to values ranging between 25 and $60 \%$. Similar percentages of survival were observed in R6 $\Delta s s r A$ when treated with $\mathrm{CM}$, in which cell death levels without protein inhibitor treatment were also remarkably higher (5-10\%) than in the wild type. The protective effect of $\mathrm{CM}$ increased at longer times and it was extended to other protein inhibitors such as EM. Incubation with both antibiotics increased survival to LVX after 2 h-treatment more than 200-fold (Figure 5D). This means that LVX lethal action in $S$. pneumoniae also requires active protein synthesis, what could explain the less susceptible phenotype of $\Delta s s r A$ cells.

\section{DISCUSSION}

In this study we provide evidence that $S$. pneumoniae relies on tmRNA for adaptation to a variety of environmental conditions, and that its inactivation reduces the ability of the pneumococcus to cope with several stresses. Our findings showed that tmRNA is not essential for growth in the pneumococcus, although its absence significantly reduced growth rate. Most bacteria require a system to resolve non-stop complexes (Keiler and Feaga, 2014). On this regard, S. pneumoniae is not an exception. The presence of a putative ArfB encoding gene has been predicted in the pneumococcal genome (Keiler and Feaga, 2014) and this is probably the reason why tmRNA is not essential for growth. Moreover, we demonstrated that insertional inactivation of tmRNA did not affect survival to internal oxidative stress induced by paraquat, but reduced the ability to survive to the lethal effect of UV irradiation and had a deleterious effect upon exposure to exogenous $\mathrm{H}_{2} \mathrm{O}_{2}$. We also demonstrated that pneumococcal cells lacking tmRNA exhibited higher susceptibility to antibiotics that inhibit protein synthesis or transcription, but not to those targeting cell wall synthesis. The increased sensitivity to protein synthesis inhibitors was rather moderate, similarly to what was previously observed for E. coli (Abo et al., 2002), Synechocystis (de la Cruz and Vioque, 2001) or Francisella tularensis (Svetlanov et al., 2012), whose ssrA null mutants were more sensitive to sublethal concentrations of these drugs. Inhibition of the translation elongation process may cause ribosome stalling, translational inaccuracy and/or read-through, leading to the accumulation of non-stop complexes (Thompson et al., 2002, 2004; Vioque and de la Cruz, 2003). Therefore, the trans-translation system confers the cells with partial resistance to certain antibiotics by dealing with ribosome pausing. In case of rifampicin, the increment in sensitivity exhibited by the $\Delta s s r A$ mutant was also moderate. A similar sensitive phenotype was observed in $F$. tularensis (Svetlanov et al., 2012) but no in E. coli or Synechocystis (de la Cruz and Vioque, 2001; Abo et al., 2002), suggesting certain differences among bacteria. This antibiotic inhibits transcription and no ribosome stalling is expected upon rifampicin treatment. However, translation and transcription are known to be coupled and defects in RNA synthesis may ultimately have consequences in translation.

Remarkably, our findings demonstrated that pneumococcal cells lacking tmRNA were more resistant to the four FQs tested (LVX, MOX, CPX, and NFX), showing both higher MIC values (twofold) and higher survival rates (up to 1100fold). Such resistant phenotype was not observed with penicillin 
A

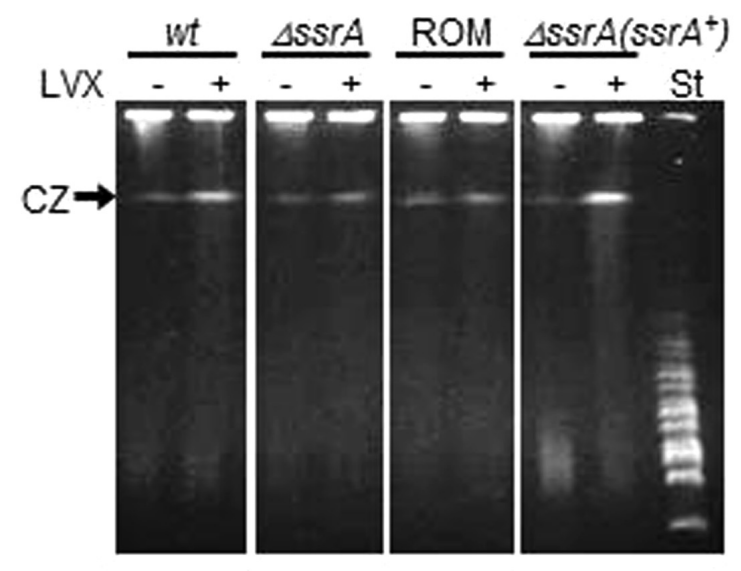

C

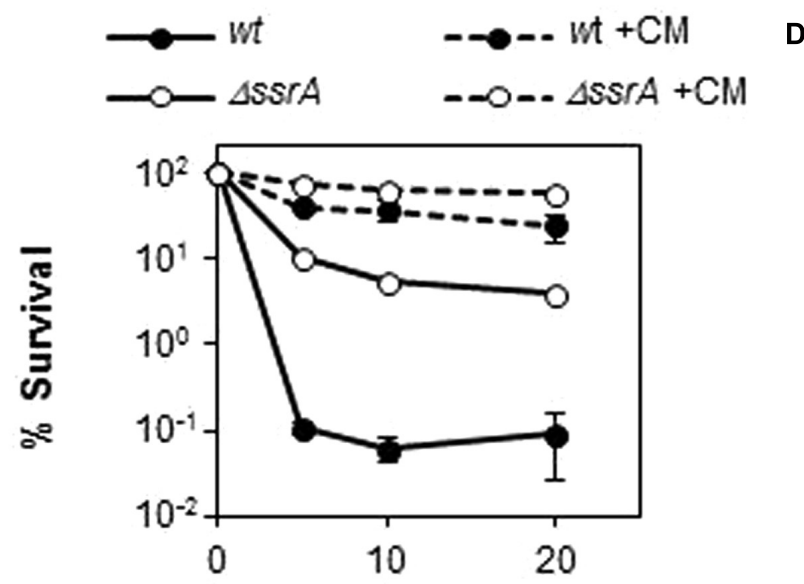

LVX concentration (MIC-fold)

B
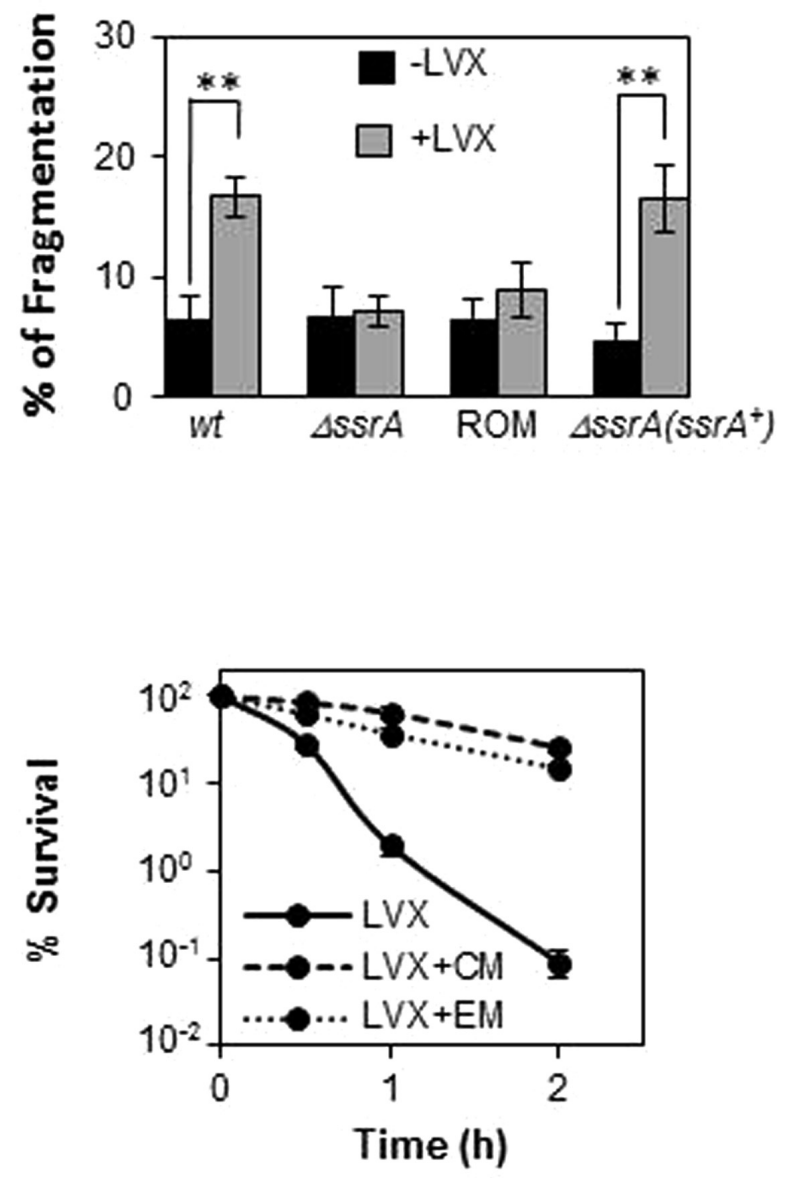

FIGURE 5 | Deficiency of tmRNA protects from chromosome fragmentation mediated by LVX. (A) Analysis of chromosome fragmentation upon LVX treatment by PFGE. Exponentially growing cultures of R6 (wt), the R6 $\Delta s s r A(\Delta s s r A)$ mutant, the complemented strain containing the $\mathrm{pROM}-\mathrm{TM}\left(\Delta s s r A\left(s s r A^{+}\right)\right)$and the R6 $\Delta$ ssrA containing the empty vector (ROM), were treated with or without 10x MIC of LVX for 30 min and analyzed by PFGE as described in Section "Materials and Methods." (B) Chromosomal fragmentation was estimated by quantification of the compression zone (CZ) relative to the intact chromosomal DNA retained in the well. Each value is the mean of at least three independent experiments and the mean values were statistically compared using Student's $t$-test $\left.*^{* * *} P<0.01\right)$.

(C) Percentage of survival to $1 \mathrm{~h}$ treatment of $\mathrm{LVX}$ at 5,10 , or $20 \times \mathrm{MIC}$ of $w t, \Delta s s \mathrm{~A}$ strains previously incubated with $10 \mu / \mathrm{ml}$ of Chloramphenicol (CM) for 10 min. St stands for the MidRange PFG Marker (Biolabs) with size ranges from 15 to $300 \mathrm{~Kb}$. (D) Percentage of survival along the time to treatment with $5 \times$ MIC of wt strains previously incubated with $10 \mu / \mathrm{ml}$ of CM or $0.3 \mu / \mathrm{ml}$ of erythromycin (EM) for 10 min. Survival was determined as described in Section "Materials and Methods."

and was not due to the lower growth rate shown by the tmRNA deletion mutant, since increasing the doubling time of wild type at $30^{\circ} \mathrm{C}$ had no the same effect. Moreover, this protective phenotype was associated to trans-translation defects and not to side effects of the tmRNA, since similar survival rates were observed in a $\Delta \operatorname{smp} B$ strain. This is the first study reporting a higher FQ-resistant phenotype associated to tmRNA inactivation. These results contrast with those previously obtained in E. coli or F. tularensis, where absence of tmRNA was previously reported to either have no effect (Abo et al., 2000; Luidalepp et al., 2005; Svetlanov et al., 2012) or to increase sensitivity (Nichols et al., 2011; Li et al., 2013) to nalidixic acid, ofloxacin, NFX or LVX. A possible explanation for the less sensitive phenotype observed in S. pneumoniae could be that depletion of tmRNA might influence membrane permeability, leading to lesser accumulation of the drug inside $\Delta s s r A$ cells. In fact, absence of tmRNA is expected to prevents tmRNAmediated tagging of abnormal proteins for degradation and to increases the levels of misfolded proteins (Gottesman et al., 1998; Herman et al., 1998; Choy et al., 2007), whose insertion into cell membrane could alter permeability. However, our results demonstrated that cells lacking tmRNA accumulated more EtBr 
and LVX than the wild type cells. Therefore, cell membrane integrity was indeed altered due to the deletion, but instead of reducing drug accumulation, it led to a significant increase in the levels of intracellular drugs. This means that tmRNA-depleted cells are somehow protected from the lethal effects associated to FQs.

ROS production contributes to FQ-lethality in S. pneumoniae. The intervening pathways between LVX and MOX initial antibiotic-target interaction and ROS formation are now known. LVX treatment inhibits Topo IV increasing fatDCE operon expression, what in turns, increases iron uptake (Ferrándiz and de la Campa, 2014). In the case of MOX, inhibition of both Topo IV and gyrase induce a transcriptomic response that results in an intracellular pyruvate increment that consequently leads to higher levels of $\mathrm{H}_{2} \mathrm{O}_{2}$ (Ferrándiz et al., 2016). Consistently, our results demonstrated that the protective effect against LVX and MOX of $\triangle s s r A$ cells was accompanied by a reduction in ROS accumulation. A similar protective effect was also observed against NFX and CPX, both of which target Topo IV (Muñoz and De La Campa, 1996), and whose induction of intracellular ROS in S. pneumoniae has not been determined. In E. coli, these FQs have been shown to act through different pathways, and while NFX-mediated killing involves ROS (Dwyer et al., 2007; Kohanski et al., 2007), CPX is able to kill bacteria anaerobically (Malik et al., 2007). Therefore, the protective effect of tmRNA absence may not be related to specific pathways for each FQ, but to a common feature to all of them. Nevertheless, since MOX addition in pneumococcus triggered a threefold reduction in $s m p B$ transcript levels (Ferrándiz et al., 2016), the involvement of tmRNA in specific regulatory circuits contributing to FQ lethality cannot be ruled out.

Independently of their target and mechanism of action, FQs reversibly trap the topoisomerase on the chromosomal DNA, in a ternary complex in which the DNA is broken (Chen et al., 1996; Malik et al., 2006). Releasing of DNA from these complexes generates deleterious double-stranded breaks (Drlica et al., 2008). Therefore, no matter the pathway used, the action of all FQs ultimately converges in lethal chromosome fragmentation. On this regard, our findings demonstrated that cells lacking tmRNA showed almost no chromosome fragmentation after LVX treatment, and that the sole tmRNA expression in trans is sufficient to completely restore DNA fragmentation to wild type levels. We also demonstrated that addition of CM or EM, which inhibit protein synthesis, drastically increased survival of pneumococci exposed to LVX. These findings confirm that LVX-mediated cell death in pneumococcus also occurs via the protein synthesis-dependent pathway and provide a possible explanation to the less susceptible phenotype of $\Delta s s r A$ cells. The absence of tmRNA is expected to imperil translation due to accumulation of stalled ribosomes in tmRNA depleted cells, which may give cells time to repair damage.

\section{CONCLUSION}

Transfer messenger RNA has a protective effect under several types of stresses in $S$. pneumoniae. Such protection is likely due to its role in rescuing of stalled ribosomes, helping the cell to recover and proceed with proper translation, and to tagging of abnormal proteins for degradation. However, upon FQ treatment, tmRNA is paradoxically harmful. The protective effect against FQs associated to tmRNA deficiency is linked to trans-translation and is due to the cumulative effect of two processes: a reduction in ROS production and a decrease in chromosome fragmentation, and translational pausing appear to be the underlying mechanism. These findings should be taking in consideration in the development of new antibiotics inhibiting trans-translation. Its requirement for viability or virulence in many pathogenic bacteria together with the low expected toxicity in host cells due to its absence in metazoans, has posed this pathway as an attractive antimicrobial target (Keiler and Alumasa, 2013; Ramadoss et al., 2013; Keiler and Feaga, 2014). However, our results evidence that inactivation of trans-translation may have side effects leading to an undesirable increase resistance to otherwise effective antibiotics. In addition, although not currently used in clinical practice, our results suggest that the combined use of FQs and antibiotics inhibiting protein synthesis might not be recommended and evidence the requirement of further studies on this matter.

\section{AUTHOR CONTRIBUTIONS}

LB, JW, MF, AG-S, and MA performed the experimental work. MA, AC, and MF participated in study conception, data interpretation, and manuscript writing. All authors participated in manuscript corrections.

\section{FUNDING}

This work was supported by the Fondo de Investigación Sanitaria (FIS) from Instituto de Salud Carlos III (PI11/00656) and Ministerio de Economía y Competitividad (BIO2014-55462-R). LB and JW were recipients of grants from the Inov Contacto C19 and 18 programs, respectively, attributed by the Agência para o Investimento e Comércio Externo de Portugal with Portuguese and European funds. AG-S was recipient of a contract funded by Instituto de Salud Carlos III (CA10/ 1103).

\section{ACKNOWLEDGMENTS}

We thank C. Herranz for invaluable technical assistance. The work was performed under the auspices of the Instituto de Salud Carlos III. 


\section{REFERENCES}

Abo, T., Inada, T., Ogawa, K., and Aiba, H. (2000). SsrA-mediated tagging and proteolysis of LacI and its role in the regulation of lac operon. EMBO J. 19, 3762-3769. doi: 10.1093/emboj/19.14.3762

Abo, T., Ueda, K., Sunohara, T., Ogawa, K., and Aiba, H. (2002). SsrA-mediated protein tagging in the presence of miscoding drugs and its physiological role in Escherichia coli. Genes Cells 7, 629-638. doi: 10.1046/j.1365-2443.2002.00549.x

Acebo, P., Martin-Galiano, A. J., Navarro, S., Zaballos, A., and Amblar, M. (2012). Identification of 88 regulatory small RNAs in the TIGR4 strain of the human pathogen Streptococcus pneumoniae. RNA 18, 530-546. doi: 10.1261/ rna.027359.111

Andisi, V. F., Hinojosa, C. A., de Jong, A., Kuipers, O. P., Orihuela, C. J., and Bijlsma, J. J. E. (2012). Pneumococcal gene complex involved in resistance to extracellular oxidative stress. Infect. Immun. 80, 1037-1049. doi: 10.1128/IAI. 05563-11

Barends, S., Zehl, M., Bialek, S., de Waal, E., Traag, B. A., Willemse, J., et al. (2010). Transfer-messenger RNA controls the translation of cell-cycle and stress proteins in Streptomyces. EMBO Rep. 11, 119-125. doi: 10.1038/embor.2009.255

Chadani, Y., Ono, K., Kutsukake, K., and Abo, T. (2011). Escherichia coli YaeJ protein mediates a novel ribosome-rescue pathway distinct from SsrA- and ArfA-mediated pathways. Mol. Microbiol. 80, 772-785. doi: 10.1111/j.13652958.2011.07607.x

Chadani, Y., Ono, K., Ozawa, S.-I., Takahashi, Y., Takai, K., Nanamiya, H., et al. (2010). Ribosome rescue by Escherichia coli ArfA (YhdL) in the absence of trans-translation system. Mol. Microbiol. 78, 796-808. doi: 10.1111/j.1365-2958. 2010.07375.x

Champoux, J. J. (2001). DNA topoisomerases: structure, function, and mechanism. Annu. Rev. Biochem. 70, 369-413. doi: 10.1146/annurev.biochem.70.1.369

Chen, C.-R., Malik, M., Snyder, M., and Drlica, K. (1996). DNA gyrase and topoisomerase IV on the bacterial chromosome: quinolone-induced DNA cleavage. J. Mol. Biol. 258, 627-637. doi: 10.1006/jmbi.1996.0274

Choy, J. S., Aung, L. L., and Karzai, A. W. (2007). Lon protease degrades transfermessenger RNA-tagged proteins. J. Bacteriol. 189, 6564-6571. doi: 10.1128/JB. 00860-07

Christensen, S. K., and Gerdes, K. (2003). RelE toxins from bacteria and Archaea cleave mRNAs on translating ribosomes, which are rescued by tmRNA. Mol. Microbiol. 48, 1389-1400. doi: 10.1046/j.1365-2958.2003.03512.x

Christensen, S. K., Pedersen, K., Hansen, F. G., and Gerdes, K. (2003). Toxinantitoxin loci as stress-response-elements: ChpAK/MazF and ChpBK cleave translated RNAs and are counteracted by tmRNA. J. Mol. Biol. 332, 809-819. doi: 10.1016/S0022-2836(03)00922-7

Clinical and Laboratory Standards Institute (2008). Performance Standards for Antimicrobial Susceptibility Testing; 18th Informational Supplement. CLSI Document M100-S18. Wayne, PA: Clinical and Laboratory Standards Institute.

de la Cruz, J., and Vioque, A. (2001). Increased sensitivity to protein synthesis inhibitors in cells lacking tmRNA. RNA 7, 1708-1716.

Deitz, W. H., Cook, T. M., and Goss, W. A. (1966). Mechanism of action of nalidixic acid on Escherichia coli III. Conditions required for lethality. J. Bacteriol. 91, $768-773$.

Drlica, K., Malik, M., Kerns, R. J., and Zhao, X. (2008). Quinolone-mediated bacterial death. Antimicrob. Agents Chemother. 52, 385-392. doi: 10.1128/AAC. 01617-06

Dwyer, D. J., Belenky, P. A., Yang, J. H., MacDonald, I. C., Martell, J. D., Takahashi, N., et al. (2014). Antibiotics induce redox-related physiological alterations as part of their lethality. Proc. Natl. Acad. Sci. U.S.A. 111, E2100-E2109. doi: 10.1073/pnas.1401876111

Dwyer, D. J., Kohanski, M. A., Hayete, B., and Collins, J. J. (2007). Gyrase inhibitors induce an oxidative damage cellular death pathway in Escherichia coli. Mol. Syst. Biol. 3:91. doi: 10.1038/msb4100135

Ferrándiz, M.-J., and de la Campa, A. G. (2014). The fluoroquinolone levofloxacin triggers the transcriptional activation of iron transport genes that contribute to cell death in Streptococcus pneumoniae. Antimicrob. Agents Chemother. 58, 247-257. doi: 10.1128/AAC.01706-13

Ferrándiz, M. J., Martín-Galiano, A. J., Arnanz, C., Zimmerman, T., and de la Campa, A. G. (2016). Reactive oxygen species contribute to the bactericidal effects of the fluoroquinolone moxifloxacin in Streptococcus pneumoniae. Antimicrob. Agents Chemother. 60, 409-417. doi: 10.1128/AAC.02299-15
Ferrándiz, M. J., Oteo, J., Aracil, B., Gómez-Garcés, J. L., and De La Campa, A. G. (1999). Drug efflux and parC mutations are involved in fluoroquinolone resistance in viridans group streptococci. Antimicrob. Agents Chemother. 43, 2520-2523.

Giudice, E., Macé, K., and Gillet, R. (2014). Trans-translation exposed: understanding the structures and functions of tmRNA-SmpB. Front. Microbiol. 5:113. doi: 10.3389/fmicb.2014.00113

Gottesman, S., Roche, E., Zhou, Y., and Sauer, R. T. (1998). The ClpXP and ClpAP proteases degrade proteins with carboxy-terminal peptide tails added by the SsrA-tagging system. Genes Dev. 12, 1338-1347. doi: 10.1101/gad.12.9. 1338

Halpern, D., Gruss, A., Claverys, J.-P., and El-Karoui, M. (2004). rexAB mutants in Streptococcus pneumoniae. Microbiol. Read. Engl. 150, 2409-2414. doi: 10.1099/ mic.0.27106-0

Herman, C., Thévenet, D., Bouloc, P., Walker, G. C., and D'Ari, R. (1998). Degradation of carboxy-terminal-tagged cytoplasmic proteins by the Escherichia coli protease HflB (FtsH). Genes Dev. 12, 1348-1355. doi: 10.1101/ gad.12.9.1348

Jacobs, M. R., Felmingham, D., Appelbaum, P. C., Grüneberg, R. N., and Alexander Project Group (2003). The Alexander Project 1998-2000: susceptibility of pathogens isolated from community-acquired respiratory tract infection to commonly used antimicrobial agents. J. Antimicrob. Chemother. 52, 229-246. doi: $10.1093 /$ jac/dkg321

Julio, S. M., Heithoff, D. M., and Mahan, M. J. (2000). ssrA (tmRNA) plays a role in Salmonella enterica serovar Typhimurium pathogenesis. J. Bacteriol. 182, 1558-1563. doi: 10.1128/JB.182.6.1558-1563.2000

Jumbe, N. L., Louie, A., Miller, M. H., Liu, W., Deziel, M. R., Tam, V. H., et al. (2006). Quinolone efflux pumps play a central role in emergence of fluoroquinolone resistance in Streptococcus pneumoniae. Antimicrob. Agents Chemother. 50, 310-317. doi: 10.1128/AAC.50.1.310-317.2006

Karzai, A. W., Roche, E. D., and Sauer, R. T. (2000). The SsrA-SmpB system for protein tagging, directed degradation and ribosome rescue. Nat. Struct. Biol. 7, 449-455. doi: 10.1038/75843

Karzai, A. W., Susskind, M. M., and Sauer, R. T. (1999). SmpB, a unique RNAbinding protein essential for the peptide-tagging activity of SsrA (tmRNA). EMBO J. 18, 3793-3799. doi: 10.1093/emboj/18.13.3793

Keiler, K. C. (2008). Biology of trans-translation. Annu. Rev. Microbiol. 62, 133-151. doi: 10.1146/annurev.micro.62.081307.162948

Keiler, K. C., and Alumasa, J. N. (2013). The potential of trans-translation inhibitors as antibiotics. Future Microbiol. 8, 1235-1237. doi: 10.2217/fmb.13. 110

Keiler, K. C., and Feaga, H. A. (2014). Resolving nonstop translation complexes is a matter of life or death. J. Bacteriol. 196, 2123-2130. doi: 10.1128/JB.014 90-14

Keiler, K. C., and Shapiro, L. (2003). tmRNA is required for correct timing of DNA replication in Caulobacter crescentus. J. Bacteriol. 185, 573-580. doi: 10.1128/ JB.185.2.573-580.2003

Keiler, K. C., Waller, P. R., and Sauer, R. T. (1996). Role of a peptide tagging system in degradation of proteins synthesized from damaged messenger RNA. Science 271, 990-993. doi: 10.1126/science.271.5251.990

Kobayashi, K., Kuwana, R., and Takamatsu, H. (2008). kinA mRNA is missing a stop codon in the undomesticated Bacillus subtilis strain ATCC 6051. Microbiol. Read. Engl. 154, 54-63. doi: 10.1099/mic.0.2007/011783-0

Kohanski, M. A., Dwyer, D. J., Hayete, B., Lawrence, C. A., and Collins, J. J. (2007). A common mechanism of cellular death induced by bactericidal antibiotics. Cell 130, 797-810. doi: 10.1016/j.cell.2007.06.049

Komine, Y., Kitabatake, M., Yokogawa, T., Nishikawa, K., and Inokuchi, H. (1994). A tRNA-like structure is present in 10Sa RNA, a small stable RNA from Escherichia coli. Proc. Natl. Acad. Sci. U.S.A. 91, 9223-9227. doi: 10.1073/pnas. 91.20.9223

Kumar, R., Shah, P., Swiatlo, E., Burgess, S. C., Lawrence, M. L., and Nanduri, B. (2010). Identification of novel non-coding small RNAs from Streptococcus pneumoniae TIGR4 using high-resolution genome tiling arrays. BMC Genomics 11:350. doi: 10.1186/1471-2164-11-350

Lacks, S. A., Lopez, P., Greenberg, B., and Espinosa, M. (1986). Identification and analysis of genes for tetracycline resistance and replication functions in the broad-host-range plasmid pLS1. J. Mol. Biol. 192, 753-765. doi: 10.1016/00222836(86)90026-4 
Li, J., Ji, L., Shi, W., Xie, J., and Zhang, Y. (2013). Trans-translation mediates tolerance to multiple antibiotics and stresses in Escherichia coli. J. Antimicrob. Chemother. 68, 2477-2481. doi: 10.1093/jac/dkt231

Li, X., Yagi, M., Morita, T., and Aiba, H. (2008). Cleavage of mRNAs and role of tmRNA system under amino acid starvation in Escherichia coli. Mol. Microbiol. 68, 462-473. doi: 10.1111/j.1365-2958.2008.06167.x

Luidalepp, H., Hallier, M., Felden, B., and Tenson, T. (2005). tmRNA decreases the bactericidal activity of aminoglycosides and the susceptibility to inhibitors of cell wall synthesis. RNA Biol. 2, 70-74. doi: 10.4161/rna.2.2.2020

Malik, M., Hussain, S., and Drlica, K. (2007). Effect of anaerobic growth on quinolone lethality with Escherichia coli. Antimicrob. Agents Chemother. 51, 28-34. doi: 10.1128/AAC.00739-06

Malik, M., Zhao, X., and Drlica, K. (2006). Lethal fragmentation of bacterial chromosomes mediated by DNA gyrase and quinolones. Mol. Microbiol. 61, 810-825. doi: 10.1111/j.1365-2958.2006.05275.x

Mann, B., van Opijnen, T., Wang, J., Obert, C., Wang, Y.-D., Carter, R., et al. (2012). Control of virulence by small RNAs in Streptococcus pneumoniae. PLoS Pathog. 8:e1002788. doi: 10.1371/journal.ppat.1002788

Moreira, R. N., Domingues, S., Viegas, S. C., Amblar, M., and Arraiano, C. M. (2012). Synergies between RNA degradation and trans-translation in Streptococcus pneumoniae: cross regulation and co-transcription of RNase R and SmpB. BMC Microbiol. 12:268. doi: 10.1186/1471-2180-12-268

Mu, X., Huan, H., Xu, H., Gao, Q., Xiong, L., Gao, R., et al. (2013). The transfermessenger RNA-small protein B system plays a role in avian pathogenic Escherichia coli pathogenicity. J. Bacteriol. 195, 5064-5071. doi: 10.1128/JB. 00628-13

Muñoz, R., and De La Campa, A. G. (1996). ParC subunit of DNA topoisomerase IV of Streptococcus pneumoniae is a primary target of fluoroquinolones and cooperates with DNA gyrase A subunit in forming resistance phenotype. Antimicrob. Agents Chemother. 40, 2252-2257.

Muto, A., Fujihara, A., Ito, K. I., Matsuno, J., Ushida, C., and Himeno, H. (2000). Requirement of transfer-messenger RNA for the growth of Bacillus subtilis under stresses. Genes Cells 5, 627-635. doi: 10.1046/j.1365-2443.2000. 00356.x

Nichols, R. J., Sen, S., Choo, Y. J., Beltrao, P., Zietek, M., Chaba, R., et al. (2011). Phenotypic landscape of a bacterial cell. Cell 144, 143-156. doi: 10.1016/j.cell. 2010.11.052

O’Brien, K. L., Wolfson, L. J., Watt, J. P., Henkle, E., Deloria-Knoll, M., McCall, N., et al. (2009). Burden of disease caused by Streptococcus pneumoniae in children younger than 5 years: global estimates. Lancet 374, 893-902. doi: 10.1016/ S0140-6736(09)61204-6

Oh, B. K., and Apirion, D. (1991). 10Sa RNA, a small stable RNA of Escherichia coli, is functional. Mol. Gen. Genet. 229, 52-56. doi: 10.1007/BF00264212

Okan, N. A., Bliska, J. B., and Karzai, A. W. (2006). A Role for the SmpBSsrA system in Yersinia pseudotuberculosis pathogenesis. PLoS Pathog. 2:e6. doi: 10.1371/journal.ppat.0020006

Pérez-Boto, D., Acebo, P., García-Peña, F. J., Abad, J. C., Echeita, M. A., and Amblar, M. (2015). Isolation of a point mutation associated with altered expression of the CmeABC efflux pump in a multidrug-resistant Campylobacter jejuni population of poultry origin. J. Glob. Antimicrob. Resist. 3, 115-122. doi: 10.1016/j.jgar.2015.03.010

Pericone, C. D., Park, S., Imlay, J. A., and Weiser, J. N. (2003). Factors contributing to hydrogen peroxide resistance in Streptococcus pneumoniae include pyruvate oxidase (SpxB) and avoidance of the toxic effects of the fenton reaction. J. Bacteriol. 185, 6815-6825. doi: 10.1128/JB.185.23.6815-6825. 2003

Piddock, L. J. V., and Johnson, M. M. (2002). Accumulation of 10 fluoroquinolones by wild-type or efflux mutant Streptococcus pneumoniae. Antimicrob. Agents Chemother. 46, 813-820. doi: 10.1128/AAC.46.3.813-820.2002

Ramadoss, N. S., Alumasa, J. N., Cheng, L., Wang, Y., Li, S., Chambers, B. S., et al. (2013). Small molecule inhibitors of trans-translation have broad-spectrum antibiotic activity. Proc. Natl. Acad. Sci. U.S.A. 110, 10282-10287. doi: 10.1073/ pnas. 1302816110

Ranquet, C., and Gottesman, S. (2007). Translational regulation of the Escherichia coli stress factor RpoS: a role for SsrA and Lon. J. Bacteriol. 189, 4872-4879. doi: 10.1128/JB.01838-06
Richards, J., Mehta, P., and Karzai, A. W. (2006). RNase R degrades non-stop mRNAs selectively in an SmpB-tmRNA-dependent manner. Mol. Microbiol. 62, 1700-1712. doi: 10.1111/j.1365-2958.2006.05472.x

Ruiz-Masó, J. A., López-Aguilar, C., Nieto, C., Sanz, M., Burón, P., Espinosa, M., et al. (2012). Construction of a plasmid vector based on the pMV158 replicon for cloning and inducible gene expression in Streptococcus pneumoniae. Plasmid 67, 53-59. doi: 10.1016/j.plasmid.2011.09.001

Sahm, D. F., Karlowsky, J. A., Kelly, L. J., Critchley, I. A., Jones, M. E., Thornsberry, C., et al. (2001). Need for annual surveillance of antimicrobial resistance in Streptococcus pneumoniae in the United States: 2-year longitudinal analysis. Antimicrob. Agents Chemother. 45, 1037-1042. doi: 10.1128/AAC.45. 4.1037-1042.2001

Schaub, R. E., Poole, S. J., Garza-Sánchez, F., Benbow, S., and Hayes, C. S. (2012). Proteobacterial ArfA peptides are synthesized from non-stop messenger RNAs. J. Biol. Chem. 287, 29765-29775. doi: 10.1074/jbc.M112.374074

Shimizu, Y. (2014). Biochemical aspects of bacterial strategies for handling the incomplete translation processes. Front. Microbiol. 5:170. doi: 10.3389/fmicb. 2014.00170

Song, J.-H., Ko, K. S., Lee, J.-Y., Baek, J. Y., Oh, W. S., Yoon, H. S., et al. (2005). Identification of essential genes in Streptococcus pneumoniae by allelic replacement mutagenesis. Mol. Cells 19, 365-374.

Sung, C. K., Li, H., Claverys, J. P., and Morrison, D. A. (2001). An rpsL cassette, janus, for gene replacement through negative selection in Streptococcus pneumoniae. Appl. Environ. Microbiol. 67, 5190-5196. doi: 10.1128/AEM.67.11. 5190-5196.2001

Svetlanov, A., Puri, N., Mena, P., Koller, A., and Karzai, A. W. (2012). Francisella tularensis tmRNA system mutants are vulnerable to stress, avirulent in mice, and provide effective immune protection. Mol. Microbiol. 85, 122-141. doi: 10.1111/j.1365-2958.2012.08093.x

Tettelin, H., Nelson, K. E., Paulsen, I. T., Eisen, J. A., Read, T. D., Peterson, S., et al. (2001). Complete genome sequence of a virulent isolate of Streptococcus pneumoniae. Science 293, 498-506. doi: 10.1126/science.1061217

Thompson, J., O'Connor, M., Mills, J. A., and Dahlberg, A. E. (2002). The protein synthesis inhibitors, oxazolidinones and chloramphenicol, cause extensive translational inaccuracy in Vivo. J. Mol. Biol. 322, 273-279. doi: 10.1016/S00222836(02)00784-2

Thompson, J., Pratt, C. A., and Dahlberg, A. E. (2004). Effects of a number of classes of $50 \mathrm{~S}$ inhibitors on stop codon readthrough during protein synthesis. Antimicrob. Agents Chemother. 48, 4889-4891. doi: 10.1128/AAC.48.12.48894891.2004

Vioque, A., and de la Cruz, J. (2003). Trans-translation and protein synthesis inhibitors. FEMS Microbiol. Lett. 218, 9-14. doi: 10.1111/j.1574-6968.2003. tb11491.x

Wang, X., and Zhao, X. (2009). Contribution of oxidative damage to antimicrobial lethality. Antimicrob. Agents Chemother. 53, 1395-1402. doi: 10.1128/AAC. 01087-08

Wang, X., Zhao, X., Malik, M., and Drlica, K. (2010). Contribution of reactive oxygen species to pathways of quinolone-mediated bacterial cell death. J. Antimicrob. Chemother. 65, 520-524. doi: 10.1093/jac/dkp486

WHO (2007). Pneumococcal conjugate vaccine for childhood immunizationWHO position paper. Wkly. Epidemiol. Rec. 82, 93-104.

Wilton, J., Acebo, P., Herranz, C., Gómez, A., and Amblar, M. (2015). Small regulatory RNAs in Streptococcus pneumoniae: discovery and biological functions. Front. Genet. 6:126. doi: 10.3389/fgene.2015.00126

Conflict of Interest Statement: The authors declare that the research was conducted in the absence of any commercial or financial relationships that could be construed as a potential conflict of interest.

Copyright () 2017 Brito, Wilton, Ferrándiz, Gómez-Sanz, de la Campa and Amblar. This is an open-access article distributed under the terms of the Creative Commons Attribution License (CC BY). The use, distribution or reproduction in other forums is permitted, provided the original author(s) or licensor are credited and that the original publication in this journal is cited, in accordance with accepted academic practice. No use, distribution or reproduction is permitted which does not comply with these terms. 